\title{
Biochemical studies on sphingolipids of Artemia franciscana: complex neutral glycosphingolipids
}

\author{
Hisao Kojima • Yukako Tohsato • Kazuya Kabayama • \\ Saki Itonori • Masahiro Ito
}

Received: 31 May 2012 /Revised: 18 July 2012 / Accepted: 20 July 2012 /Published online: 14 August 2012

(C) The Author(s) 2012. This article is published with open access at Springerlink.com

\begin{abstract}
Brine shrimp are primitive crustacean arthropodal model organisms, second to daphnia, which can survive in high-salinity environments. Their oviposited cysts, cuticlecovered diapausing eggs, are highly resistant to dryness. To elucidate specialties of brine shrimp, this study characterized glycosphingolipids, which are signal transductionassociated material. A group of novel and complex fucosyl glycosphingolipids were separated and identified from cysts of the brine shrimp Artemia franciscana by repeated lipid extraction, alkaline methanolysis, acid treatment, successive column chromatography, and post-source decay measurements by matrix-assisted laser desorption/ionization time-offlight mass spectrometry. Structures of the glycosphingolipids were elucidated by conventional structural characterization and mass spectrometry, and the compounds were identified as GlcNAc $\beta$ 1-3GalNAc $\beta 1$-4(GlcNAc $\alpha 1-2$ Fuc $\alpha 1$ 3)GlcNAc $\beta 1$-3Man $\beta 1-4$ Glc $\beta 1$-Cer, GalNAc $\beta 1-4$ (Fuc $\alpha 1$ -
\end{abstract}

Electronic supplementary material The online version of this article (doi:10.1007/s10719-012-9436-8) contains supplementary material, which is available to authorized users.

H. Kojima $\cdot$ K. Kabayama

Institute of Glycoscience, Tokai University,

4-1-1 Kitakaname,

Hiratsuka, Kanagawa 259-1292, Japan

S. Itonori

Department of Chemistry, Faculty of Liberal Arts and Education,

Shiga University,

2-5-1 Hiratsu,

Otsu, Shiga 520-0862, Japan

Y. Tohsato $\cdot$ M. Ito $(\triangle)$

Department of Bioinformatics, College of Life Sciences,

Ritsumeikan University,

1-1-1 Nojihigashi,

Kusatsu, Shiga 525-8577, Japan

e-mail: maito@sk.ritsumei.ac.jp
$3)$ GlcNAc $\beta 1$ - 3 GalNAc $\beta 1$ - 4(GlcNAc $\alpha 1-2$ Fuc $\alpha 1$ 3)GlcNAc $\beta$ 1-3Man $\beta$ 1-4Glc $\beta$ 1-Cer, and GalNAc $\beta 1-4$ (GlcNAc $\alpha 1-2$ Fuc $\alpha 1-3$ ) GlcNAc $\beta 1$ - 3 GalNAc $\beta 1$ - 4 (GlcNAc $\alpha 1-2$ Fuc $\alpha 1-3)$ GlcNAc $\beta 1-3$ Man $\beta 1-4 G l c \beta 1-C e r$. These compounds also contained a branching, non-arthroseries disaccharide with an $\alpha$-GlcNAc terminus, similar to that found in a previously reported ceramide hexasaccharide $\left(\mathrm{III}^{3}(\mathrm{GlcNAc} \alpha 2 \mathrm{Fuc} \alpha)-\mathrm{At}_{4} \mathrm{Cer}\right)$. The glycans within these complex GSLs are longer than reported glycans of the animal kingdom containing $\alpha$-GlcNAc terminus. These complex GSLs as well as the longest GSL with ten sugar residues, ceramide decasaccharide (CDeS), contain the fucosylated LacdiNAc sequence reported to associate with parasitism/ immunosuppression and the $\alpha$-GlcNAc terminus reported to show a certain antibacterial effect in other reports. CDeS, the longest GSL of this species, was found in the highest amount, which indicates that CDeS may be functionally important.

Keywords Sphingosine $\cdot$ Fucomannolipid $\cdot$ Terminal $\alpha$ - $N$-acetylglucosamine residue $\cdot$ Structure characterization · Branchiopoda $\cdot$ Dormant cyst

$\begin{array}{ll}\begin{array}{l}\text { Abbreviations } \\ \text { CDeS }\end{array} & \text { Ceramide decasaccharide } \\ \text { CHpS } & \text { Ceramide heptasaccharide } \\ \text { CHS } & \text { Ceramide hexasaccharide } \\ \text { CNS } & \text { Ceramide nonasaccharide } \\ \text { COS } & \text { Ceramide octasaccharide } \\ \text { GC } & \text { Gas chromatography } \\ \text { GSL } & \text { Glycosphingolipid } \\ { }^{1} \text { H-NMR } & \text { Proton nuclear magnetic resonance } \\ \text { HPTLC } & \text { High-performance thin-layer } \\ & \text { chromatography } \\ \text { MALDI-TOF MS } & \begin{array}{l}\text { Matrix-assisted laser desorption/ } \\ \text { ionization time-of-flight mass } \\ \end{array} \\ & \text { spectrometry }\end{array}$




\section{Introduction}

Glycosphingolipid (GSL) is an amphipathic compound consisting of a sugar chain and a ceramide composed of a fatty acid and sphingoid base. GSLs are ubiquitous on the outer surface of the plasma membrane in animal cells, aggregated into patches called microdomains, and play an essential role in intercellular interaction and recognition [1-3]. However, a comprehensive understanding of GSL function has not yet been attained because of the structural complexity of the sugar chain and ceramide moiety $[4,5]$.

The study of invertebrate GSLs increases our understanding of human GSLs, helps determine which types of sphingolipids are essential for living animals, and clarifies evolutionary relationships between phyla in the animal kingdom. In the phylum Arthropoda, structural analyses of GSLs have been performed with flies $[6,7]$, and a characteristic arthro-series sugar chain (GlcNAc $\beta 3 \mathrm{Man} \beta 4 \mathrm{GlcCer} ; \mathrm{At}_{3} \mathrm{Cer}$ ) has been characterized. Functional analyses of GSLs by knockout experiments of egghead and brainiac have shown that $\mathrm{At}_{3} \mathrm{Cer}$ is essential for insect development [8]. Furthermore, $\mathrm{At}_{3} \mathrm{Cer}$ was detected in flies, including Lucilia caesar and Calliphora vicina, as well as in arthropods (the millipede Parafontaria laminata armigera) and crustaceans (Euphausia superba, Macrobrachium nipponense) [5]. We have further demonstrated the existence of $\mathrm{At}_{3} \mathrm{Cer}$ and some shorter GSLs, including GlcCer (CMS), mactosylceramide (MacCer, CDS), $\mathrm{II}^{3} \mathrm{Fuc} \alpha$-MacCer (nonarthro-CTS), $\mathrm{At}_{4} \mathrm{Cer}(\mathrm{CTeS}), \mathrm{II}^{3}$ (GlcNAc $\alpha 2$ Fuc $\alpha$ )-MacCer (nonarthro-CTeS), $\mathrm{III}^{3} \mathrm{Fuc} \alpha-\mathrm{At}_{4} \mathrm{Cer}$ (CPS), and $\mathrm{III}^{3}(\mathrm{GlcNAc} \alpha 2 \mathrm{Fuc} \alpha)-\mathrm{At}_{4} \mathrm{Cer}$ (CHS), in cysts of the brine shrimp Artemia franciscana [9]. However, it is more difficult to identify structural aspects of the sugar chain in complex GSLs than it is in shorter GSLs. Identifying the sugar chain in certain complex GSLs, which may be mixed with GSLs bound to similar oligosaccharides, depends on faint differences in polarity to determine long sugar sequences and the positions of substituted sugar residues at branching points. Several relatively complicated strategies have been employed to identify the structures of complex neutral GSLs, such as successive enzymatic degradation with exoglycosidase, chemical degradation to liberate partial oligosaccharides followed by Gas-liquid chromatography (GC) analysis, and fast atom bombardment (FAB) mass analysis of permethylated GSL to elucidate sugar sequences. In fact, there are relatively few reports that detail the structural analyses of complex GSLs in invertebrates. Complex GSLs have been identified in the green-bottle fly $L$. caesar and the blowfly $C$. vicina $[10,11]$, the human blood fluke Schistosoma mansoni [12-14], the bivalves Corbicula sandai [15] and Hyriopsis schlegeli [16], the seawater bivalve Meretrix lusoria [17], and the oyster Ostrea gigas [5].

The current study uses post-source decay (PSD) measurements coupled with matrix-assisted laser desorption/ionization time-of-flight mass spectrometry (MALDI-TOF MS) to analyze the structures of complex GSLs in diapausing eggs (cysts) of the brine shrimp A. franciscana, a crustacean arthropod harvested from the Great Salt Lake. These complex GSLs contain seven to ten sugar chains and exhibit a hybrid structure of core arthro-series sugar chains with a branching non-arthroseries disaccharide (GlcNAc $\alpha 2$ Fuc $\alpha$ ).

\section{Materials and methods}

Separation of ceramide heptasaccharide $\left(\mathrm{CHpS}_{1}, \mathrm{CHpS}_{2}\right)$, ceramide octasaccharide $\left(\mathrm{COS}_{1}\right)$, and ceramide decasaccharide (CDeS)

Neutral GSL fractions were prepared as previously reported [9] and applied to a column of Iatrobeads (6RS-8060, Mitsubishi Kagaku Iatron Inc. Tokyo). The neutral GSLs were eluted with two linear gradient elution systems of $\mathrm{C} / \mathrm{M} / \mathrm{W}$ with compositions from 80:20:1 (v/v/v, $255 \mathrm{~mL})$ to $50: 50: 5$ $(\mathrm{v} / \mathrm{v} / \mathrm{v}, 325 \mathrm{~mL})$ and from 50:50:5 (v/v/v, $252 \mathrm{~mL})$ to $20: 80: 10$ $(\mathrm{v} / \mathrm{v} / \mathrm{v}, 330 \mathrm{~mL})$. Three-milliliter fractions were collected in each tube, and aliquots from every third tube were analyzed by high-performance thin-layer chromatography (HPTLC). Fractionated GSLs were analyzed by MALDI-TOF MS. $\mathrm{CHpSes}$ are denoted as $\mathrm{CHpS}_{1}$ and $\mathrm{CHpS}_{2}$ according to their order of elution, respectively. Similarly, COSes are denoted as $\mathrm{COS}_{1}$ and $\mathrm{COS}_{2}$.

Separation of $\mathrm{COS}_{2}$ and ceramide nonasaccharide (CNS)

For isolation of $\mathrm{COS}_{2}$ and CNS, an independently prepared neutral GSL fraction $(88 \mathrm{mg})$ was applied to an Iatrobeads column $(\phi 1.0 \times 56 \mathrm{~cm})$. The neutral GSLs were eluted by a stepwise gradient elution system with one column volume each $(44 \mathrm{~mL})$ of pure chloroform, C/M 9:1 (v/v), C/M/W 80:20:1 (v/v/v), 70:30:3, 60:40:4, 50:50:5, 40:60:6, 30:70:7, 20:80:8, 10:90:9, and methanol/water 1:1 (v/v). The C/M/W 20:80:8 fraction including $\mathrm{COS}_{2}$ and CNS was further separated on a HPLC system (Shimadzu LC-10A) with an Iatrobeads column $(\phi 1.0 \times 55 \mathrm{~cm})$ and eluted with a 75:30:5 $(\mathrm{v} / \mathrm{v} / \mathrm{v})$ mixture of 1-propanol:water: $28 \%$ ammonium hydroxide at a flow rate of $1 \mathrm{~mL} / \mathrm{min}$. Three-milliliter fractions were collected in each tube, and aliquots from every third tube were tested by HPTLC. To remove silicic acid from the ammonium column, a brief purification with a Sep-pak C18 cartridge was done as follows: dried crude $\mathrm{COS}_{2}$ and $\mathrm{CNS}$ were dissolved in $2 \mathrm{~mL}$ of methanol, added to $6 \mathrm{~mL}$ of $50 \mathrm{mM} \mathrm{NaCl}$, and applied to a Sep-pak C18 cartridge equilibrated with $25 \mathrm{~mL}$ each of water, methanol, and $50 \mathrm{mM} \mathrm{NaCl}$, respectively. The cartridges were desalted with $30 \mathrm{~mL}$ of water, and the purified $\mathrm{COS}_{2}$ and CNS were eluted by $10 \mathrm{~mL}$ of methanol and dried under a nitrogen stream. 
Solvent system for thin-layer chromatography (TLC)

The following solvent systems were used for TLC: C/M/W $(60: 40: 10, \mathrm{v} / \mathrm{v} / \mathrm{v}$ and 55:45:10, v/v/v) and 1-propanol:water:28\% ammonium hydroxide $\left(1-\mathrm{PrOH} / \mathrm{W} / \mathrm{NH}_{4} \mathrm{OH}\right)$ $(70: 30: 5, \mathrm{v} / \mathrm{v} / \mathrm{v})$. After QAE-Sephadex and Florisil column chromatography, the eluates were visualized on silica gel 60 TLC plates (Merck KGaA, Germany) by spraying with orcinol- $\mathrm{H}_{2} \mathrm{SO}_{4}$ reagent [18] followed by heating at $110{ }^{\circ} \mathrm{C}$. To develop isolated GSLs at high resolution, silica gel 60 HPTLC plates (Merck KGaA, Germany) were used after separation on an Iatrobeads column.

\section{Gas chromatography}

GC analyses of GSL components, such as sugars, fatty acids, and sphingoids, and methylation procedures were performed as described previously [9]. For the GC analysis, the following amount of GSL was used: $0.2 \mathrm{mg}$ for sugar component analysis, fatty acid analysis, and methylation study, and $0.3 \mathrm{mg}$ for sphingoid analysis.

Matrix-assisted laser desorption/ionization time-of-flight mass spectrometry (MALDI-TOF MS)

MALDI-TOF MS analysis was performed using a Shimadzu Axima Confidence MALDI Mass Spectrometer with a nitrogen laser $(337 \mathrm{~nm})$. The matrix $\alpha$-cyano-4-hydroxycinnamic acid (CHCA: high-purity mass-spectrometric grade) was purchased from Shimadzu GLC (Tokyo, Japan). About $4 \mu \mathrm{g}$ of GSL was loaded on to a MALDI plate and air-dried. Subsequently, $1 \mu \mathrm{L}$ of CHCA dissolved in $50 \%$ ethanol at a saturating concentration was loaded 4 times on the dried GSL. External mass calibration was provided by the $[\mathrm{M}+\mathrm{Na}]^{+}$ions of angiotensin I (1296.96 mass units; Sigma-Aldrich Co., USA) and bradykinin fragments I-V (573.31 mass units; Sigma-Aldrich Co., USA).

Proton nuclear magnetic resonance spectroscopy

( ${ }^{1} \mathrm{H}-\mathrm{NMR}$ spectroscopy)

Anomeric configurations were confirmed by ${ }^{1} \mathrm{H}-\mathrm{NMR}$ as previously reported [9].

\section{Results}

Purified neutral glycosphingolipids

Figure 1 shows a developed TLC plate with separated GSLs. The GSLs with less than six sugar residues, corresponding to lanes $2-9$ in Fig. 1a, have been previously reported [9]. The yields of purified GSLs obtained from $1.8 \mathrm{~kg}$ of brine shrimp a

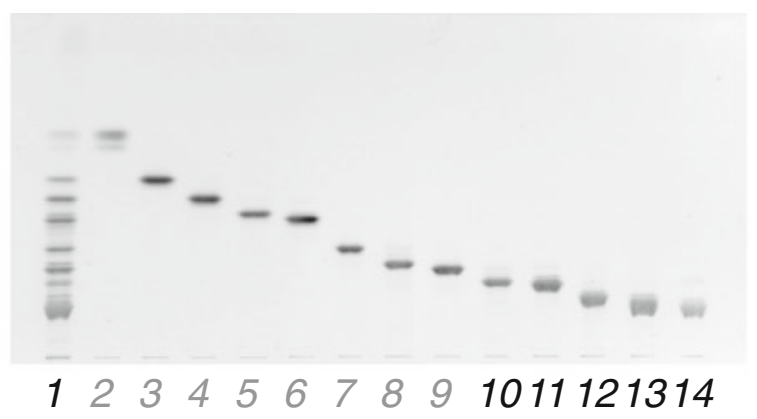

b

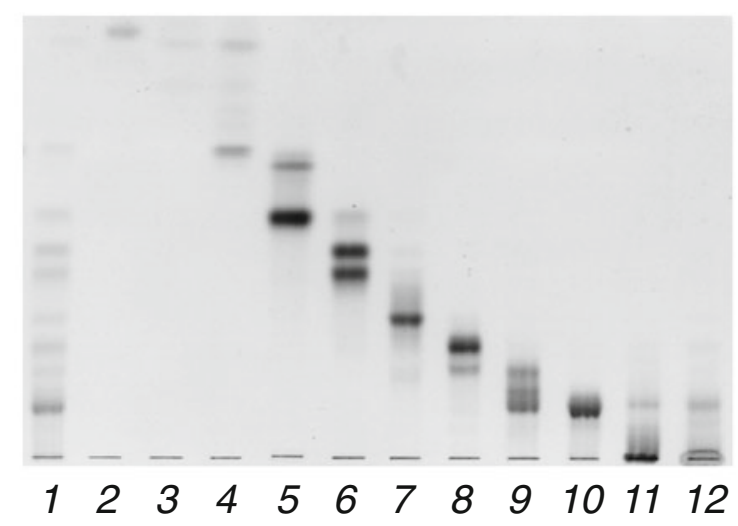

C

1-PrOH/W/NH4OH 70:30:5

$\mathrm{C} / \mathrm{M} / \mathrm{W}$
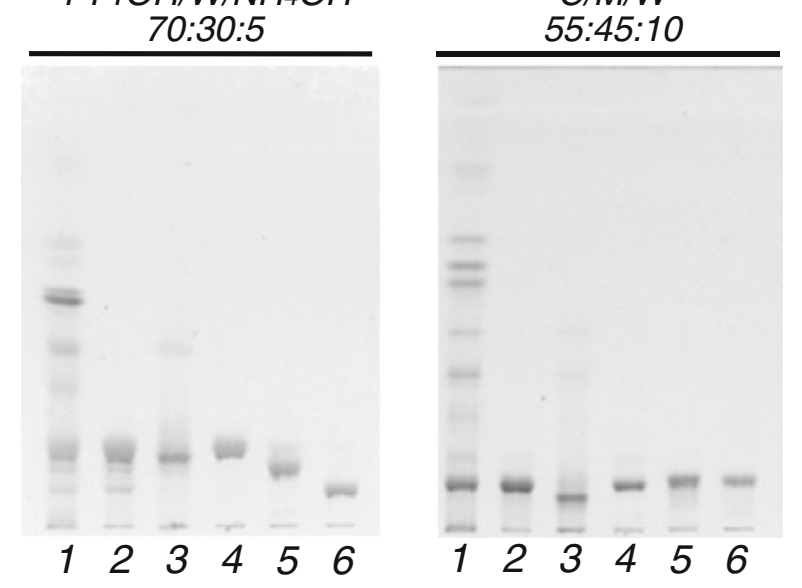

Fig. 1 A thin-layer chromatogram shows the separation of neutral glycosphingolipids separated from the brine shrimp A. franciscana. a Fractionation by linear gradient elution. Lane 1, total neutral glycosphingolipid fraction; lanes 2-9, previously reported CMS, CDS, nAtCTS, AtCTS, nAtCTeS, AtCTeS, CPS, and CHS, respectively; lane 10, $\mathrm{CHpS}_{1}$; lane 11, $\mathrm{CHpS}_{2}$; lane 12, $\mathrm{COS}_{1}$; lane 13, mixture of $\mathrm{COS}_{2}$, CNS, and CDeS; lane 14, CDeS. b Fractionation by stepwise elution. Lane 1, total neutral glycosphingolipid fraction; lanes 2 and 3, nonpolar material fraction; lane 4, CMS; lane 5, CMS and CDS; lane 6, nAtCTS, AtCTS, and nAtCTeS; lane 7, AtCTeS; lane 8, CPS and CHS; lane 9, $\mathrm{CHpS}_{1}, \mathrm{CHpS}_{2}$, and $\mathrm{COS}_{1}$; lane 10, mixture of $\mathrm{COS}_{2}, \mathrm{CNS}$, and CDeS; lanes 11 and 12, non-GSL fractions. c Purification of the fraction containing $\mathrm{COS}_{2}$, CNS, and CDeS by Iatrobeads column chromatography using ammoniacal propanol. Lane 1, total neutral glycosphingolipid fraction; lane 2, before fractionation; lane 3, non-GSL fraction; lane 4, CDeS; lane 5, CNS; lane 6, $\operatorname{COS}_{2}$. The HPTLC (a and c) and TLC (b) plates were developed in (a and b) C/M/W (60:40:10, v/v/v), (c) 1 propanol/water/ammonium hydroxide $(70: 30: 5, \mathrm{v} / \mathrm{v} / \mathrm{v})$ or $\mathrm{C} / \mathrm{M} / \mathrm{W}$ $(55: 45: 10, \mathrm{v} / \mathrm{v} / \mathrm{v})$. The spots were visualized by orcinol- $\mathrm{H}_{2} \mathrm{SO}_{4}$ reagent 
cysts were $1.0 \mathrm{mg}\left(\mathrm{CHpS}_{1}\right), 1.3 \mathrm{mg}\left(\mathrm{CHpS}_{2}\right), 1.3 \mathrm{mg}\left(\mathrm{COS}_{1}\right)$, and $17.7 \mathrm{mg}(\mathrm{CDeS}) \cdot \mathrm{COS}_{2}$ and $\mathrm{CNS}$ were eluted almost simultaneously and with relatively small yields. Therefore, to separate these two lipids, the entire procedure from lipid extraction to purification was repeated with an additional purification step capable of separating $\mathrm{COS}_{2}$ and CNS. The yield of Iatrobeads column chromatography after stepwise elution was as follows: $\sim 1 \mathrm{mg}$ (lane 2), $5.6 \mathrm{mg}$ (lane 3), $18.6 \mathrm{mg}$ (lane 4), $2.6 \mathrm{mg}$ (lane 5), $10.7 \mathrm{mg}$ (lane 6), $5.5 \mathrm{mg}$ (lane 7), $8.8 \mathrm{mg}$ (lane 8), $8.1 \mathrm{mg}$ (lane 9), $19.3 \mathrm{mg}$ (lane 10), $1.5 \mathrm{mg}$ (lane 11), and $3.3 \mathrm{mg}$ (lane 12) (Fig. 1b). Crude $\mathrm{COS}_{2}$ $(1.4 \mathrm{mg})$ and CNS $(\sim 1 \mathrm{mg})$ were separated with an eluent of ammoniacal propanol. However, it was revealed in subsequent MALDI-TOF MS spectra that both $\mathrm{COS}_{2}$ and CNS preparations contained silicic acid. Further purification using a Sep-pak C18 cartridge was performed and the resulting lipids were again analyzed by MALDI-TOF MS. The nonGSL fraction was analyzed on the basis of the mass spectrum.

\section{Sugar composition}

Each GSL was revealed to be an $\mathrm{N}$-acetyl-O-trimethylsilyl derivatized methylglycoside by GC analysis. Sugar compositions were speculated according to their GCs: $\mathrm{CHpS}_{1}$ and $\mathrm{CHpS}_{2}$ yielded Glc, Man, Fuc, GlcNAc, and GalNAc in a molar ratio of 1:1:1:3:1; $\operatorname{COS}_{1}$ yielded Glc, Man, Fuc, GlcNAc, and GalNAc in a molar ratio of 1:1:1:3:2; and CDeS yielded Glc, Man, Fuc, GlcNAc, and GalNAc in a molar ratio of 1:1:2:4:2 (see Table 1).

\section{Methylation analysis}

The partially methylated alditol acetates derived from the obtained GSLs were separated by GC, as shown in Fig. 2 . The methylation analysis revealed 1,2,5-tri- $O$-acetyl-3,4-di$O$-methylfucitol (1,2Fuc), 1,4,5-tri- $O$-acetyl-2,3,6-tri- $O$ methylglucitol $(1,4 \mathrm{Glc}), 1,3,5$-tri- $O$-acetyl-2,4,6-tri- $O$ methylmannitol (1,3Man), 1,5-di- $O$-acetyl-3,4,6-tri- $O$ methyl- $N$-acetylglucosaminitol ( $1 \mathrm{GlcNAc}$ ), 1,5-di- $O$-acetyl-3,4,6-tri- $O$-methyl- $N$-acetylgalactosaminitol (1GalNAc), 1,3,5-tri-O-acetyl-4,6-di-O-methyl- $N$ -

Table 1 Molar ratios of sugar compositions in the complex neutral glycosphingolipids purified from the brine shrimp A. franciscana. The methylglycoside TMS derivatives of each GSL were analyzed by GC, and the results were expressed relative to Glc $(=1.0)$

\begin{tabular}{lccccc}
\hline & Glc & Man & Fuc & GlcNAc & GalNAc \\
\hline $\mathrm{CHpS}_{1}$ & 1.0 & 1.0 & 0.8 & 3.2 & 1.5 \\
$\mathrm{CHpS}_{2}$ & 1.0 & 1.0 & 0.9 & 3.5 & 1.8 \\
$\mathrm{COS}_{1}$ & 1.0 & 0.9 & 0.9 & 3.5 & 2.4 \\
$\mathrm{CDeS}$ & 1.0 & 0.9 & 1.6 & 3.9 & 2.5 \\
\hline
\end{tabular}

acetylglucosaminitol (1,3GlcNAc), and 1,3,4,5-tetra- $O$-acetyl-6- $O$-methyl- $N$-acetylglucosaminitol $(1,3,4 \mathrm{GlcNAc})$ from $\mathrm{CHpS}_{1}$; 1,4Glc, 1,3Man, 1,2Fuc, $1 \mathrm{GlcNAc}, 1,3,5$-tri- $O$-acetyl-4,6-di- $O$-methyl- $N$-acetylgalactosaminitol (1,3GalNAc), and 1,3,4GlcNAc from $\mathrm{CHpS}_{2}$; 1,2Fuc, 1,4Glc, 1,3 Man, 1 GlcNAc, 1 GalNAc, 1,4,5-tri-O-acetyl-3,6-di- $O$-methyl- $N$ acetylglucosaminitol (1,4GlcNAc), 1,3GalNAc, and 1,3,4GlcNAc from $\mathrm{COS}_{1}$; 1,5-di- $O$-acetyl-2,3,4-tri- $O$-methylfucitol (1Fuc), 1,4Glc, 1,3Man, 1GalNAc, 1,3GalNAc, and 1,3,4GlcNAc from $\mathrm{COS}_{2}$; 1Fuc, 1,2Fuc, 1,4Glc, 1,3Man, $1 \mathrm{GlcNAc}, 1 \mathrm{GalNAc}, 1,3 \mathrm{GalNAc}$, and 1,3,4GlcNAc from CNS; 1,2Fuc, 1,4Glc, 1,3 Man, 1GlcNAc, 1GalNAc, 1,3GalNAc, and 1,3,4GlcNAc from CDeS. 1,4Glc and 1,3Man were eluted at the same retention time and observed as a high peak B. Although methylation analysis of $\mathrm{CHpS}_{1}$ showed the presence of $1,3 \mathrm{GalNAc}$, $\mathrm{CHpS}_{1}$ also contained a small amount of $\mathrm{CHpS}_{2}$ as demonstrated by HPTLC analysis using an ammoniacal solvent (Data not shown).

\section{Aliphatic components}

Aliphatic components such as fatty acids and sphingoids were identified by GC (Table 2). The majority of the fatty acids were saturated with chain lengths from $\mathrm{C}_{16}$ to $\mathrm{C}_{24}$, with $\mathrm{C}_{22}$ being the most predominant. The monoenoic acid of $\mathrm{C}_{22}$ was common in all of the GSLs. In some GSLs, the odd-numbered saturated fatty acids $\mathrm{C}_{21}$ and $\mathrm{C}_{23}$ were also detected in low amounts. The sphingoid components of the GSLs were composed of $d 16: 1$ and d17:1. In each case, the amount of d16:1 was approximately double that of $\mathrm{d} 17: 1$.

\section{MALDI-TOF MS analysis}

The positive in-source decay mode of MALDI-TOF MS confirmed the putative structures of the six purified GSLs (Fig. 3). Each GSL mass spectrum contained peaks attributed to two major monoisotopic $[\mathrm{M}+\mathrm{Na}]^{+}$ion species, the ceramide moieties of d16:1-22:0 and d17:1-22:0. For $\mathrm{CHpS}_{1}$, these peaks correspond to ions at $\mathrm{m} / z 1899.47$ and 1913.42 with one mole each of Glc, Man, GalNAc, and Fuc and three moles of GlcNAc (Fig. 3a). For $\mathrm{CHpS}_{2}$, the peaks correspond to ions at $\mathrm{m} / \mathrm{z}$ 1898.82 and 1912.78 with one mole each of Glc, Man, GalNAc, and Fuc and three moles of GlcNAc (Fig. 3b). For $\mathrm{COS}_{1}$, ion peaks at $\mathrm{m} / \mathrm{z} 2101.84$ and 2115.81 indicated one mole each of Glc, Man, and Fuc, two moles of GalNAc, and three moles of GlcNAc (Fig. 3c). For $\mathrm{COS}_{2}$, the ion peaks at $m / z 2044.96$ and 2058.95 corresponded to one mole each of Glc, Man, two moles each of Fuc, GalNAc, and GlcNAc and three moles of GlcNAc (Fig. 3d). For CNS, the ion peaks at $\mathrm{m} / \mathrm{z} 2248.38$ and 2262.31 corresponded to one mole each of Glc and Man, two moles of GalNAc and Fuc, and three moles of GlcNAc (Fig. 3e). For CDeS, the ion peaks at $\mathrm{m} / z 2451.45$ and 2465.42 corresponded 
Fig. 2 Gas chromatograms of partially methylated alditol acetates derived from the separated GSLs. (a) $\mathrm{CHpS}_{1}$; (b) $\mathrm{CHpS}_{2} ;$ (c) $\mathrm{COS}_{1} ;$ (d) $\mathrm{COS}_{2}$; (e) CNS; (f) CDeS; $A, 1,2$ Fuc; $B, 1,4 \mathrm{Glc}$ and $1,3 \mathrm{Man} ; C$, 1GlcNAc; $D$, 1 GalNAc; $E$, $1,3 \mathrm{GlcNAc} ; F, 1,3,4 \mathrm{GlcNAc}$; $G, 1,3 \mathrm{GalNAc} ; H, 1,4 \mathrm{GlcNAc}$; $I, 1$ Fuc, *, contaminant of phthalic acid-like material

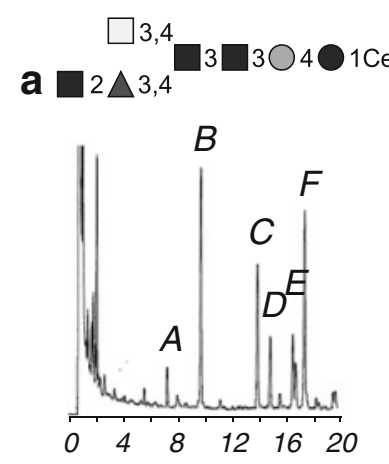

b $\quad \square_{2} \triangle_{4} \square^{3} \square_{4} \bigcirc 1 \mathrm{Cer}$
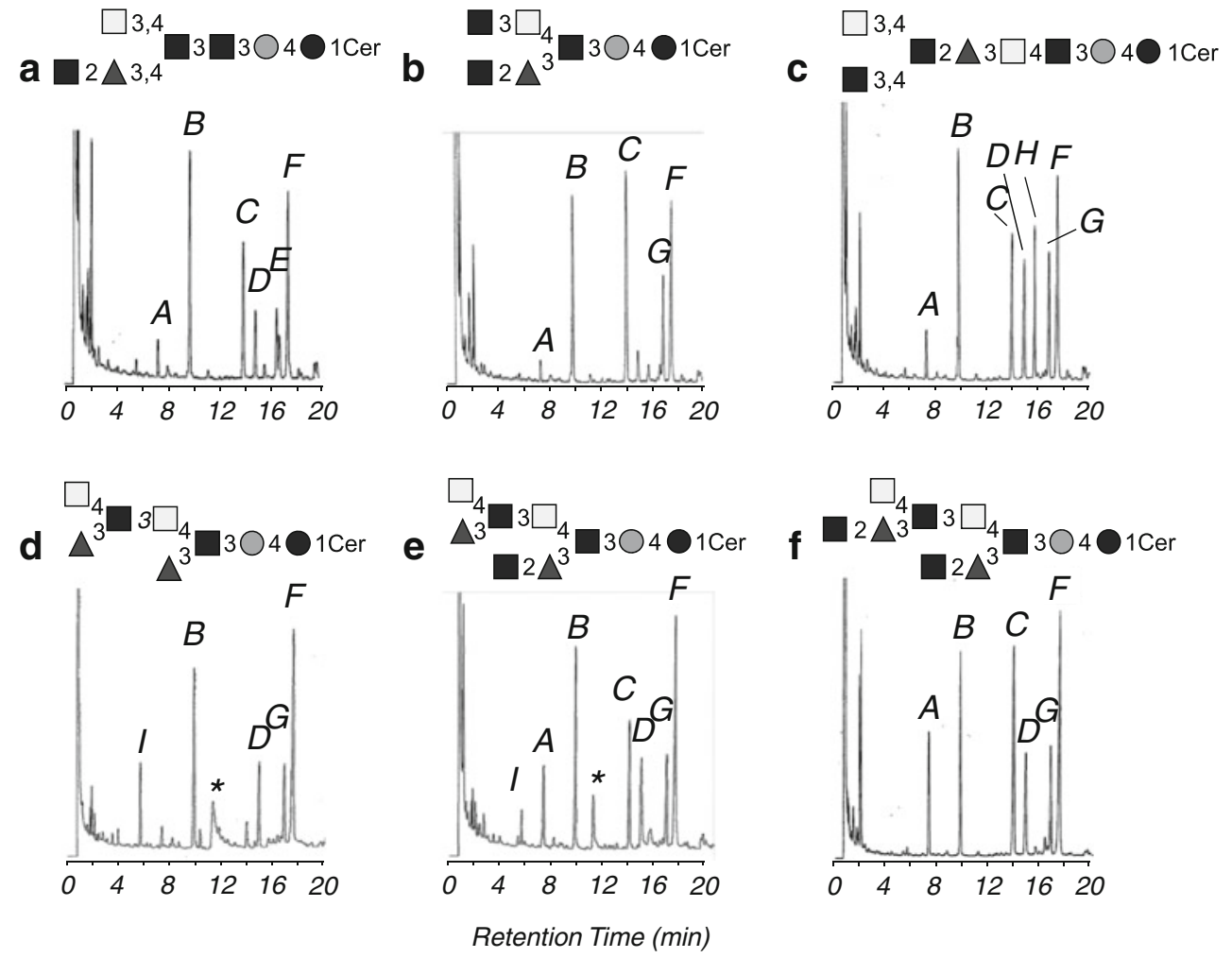

to one mole each of Glc and Man, two moles of GalNAc and Fuc, and four moles of GlcNAc (Fig. 3f). Detailed masses of

Table 2 Ceramide composition of the neutral glycosphingolipids purified from $A$. franciscana

\begin{tabular}{lcccc}
\hline Fatty acid (\%) & $\mathrm{CHpS}_{1}$ & $\mathrm{CHpS}_{2}$ & $\mathrm{COS}_{1}$ & $\mathrm{CDeS}$ \\
\hline $16: 1$ & $-{ }^{\mathrm{b}}$ & - & - & $\operatorname{tr}^{\mathrm{c}}$ \\
$16: 0$ & 1.0 & $\operatorname{tr}$ & 1.1 & 4.1 \\
$18: 1$ & - & - & - & 3.4 \\
$18: 0$ & 3.7 & 5.6 & 4.8 & 5.8 \\
$20: 0$ & 1.5 & 2.0 & 1.9 & 2.1 \\
$21: 0$ & $\operatorname{tr}$ & 1.1 & 1.0 & 1.0 \\
$22: 1$ & 4.2 & 3.8 & 3.8 & 1.1 \\
$22: 0$ & 84.3 & 84.4 & 82.2 & 79.4 \\
$23: 0$ & 1.4 & 1.1 & 1.3 & 1.1 \\
$24: 1$ & 1.0 & $\operatorname{tr}$ & 1.4 & - \\
$24: 0$ & 2.9 & 2.0 & 2.5 & 2.0 \\
& & & & \\
Sphingoid (\%) & & & & \\
d16:1 & 66.7 & 69.3 & 65.7 & 62.3 \\
d17:1 & 33.3 & 30.7 & 34.3 & 37.7 \\
\hline
\end{tabular}

${ }^{\text {a }}$ Dihydroxy sphingoid

${ }^{\mathrm{b}}$ Not detected

${ }^{\mathrm{c}}$ Trace ions other than those corresponding to the major $[\mathrm{M}+\mathrm{Na}]^{+}$ion species are summarized in Supplemental table.

The sugar sequence of each GSL was determined by MALDI-TOF PSD measurements, as shown in Fig. 4. The predominant $[\mathrm{M}+\mathrm{Na}]^{+}$ion was chosen as the precursor ion in MALDI-PSD fragment spectra. All fragment ions were observed as sodium adducts. In the PSD mass spectrum of $\mathrm{CHpS}_{1}$, fragment ions showing a neutral loss of sugar were observed at $\mathrm{m} / \mathrm{z} 1697\left([\mathrm{M}-\mathrm{HexNAc}+\mathrm{Na}]^{+}\right), 1551$ $\left([\mathrm{M}-\mathrm{HexNAc}-\mathrm{Fuc}+\mathrm{Na}]^{+}\right), 1495\left([\mathrm{M}-2 \mathrm{HexNAc}+\mathrm{Na}]^{+}\right)$, $1348\left([\mathrm{M}-2 \mathrm{HexNAc}-\mathrm{Fuc}+\mathrm{Na}]^{+}\right), 1144([\mathrm{M}-3 \mathrm{HexNAc}-$ $\left.\mathrm{Fuc}+\mathrm{Na}]^{+}\right), 941\left([\mathrm{M}-4 \mathrm{HexNAc}-\mathrm{Fuc}+\mathrm{Na}]^{+}\right)$, and 779 $\left([\mathrm{M}-4 \mathrm{HexNAc}-\mathrm{Fuc}-\mathrm{Hex}+\mathrm{Na}]^{+}\right)$, corresponding to CMS with d16:1/C22:0 (Fig. 4a). In the PSD mass spectrum of $\mathrm{CHpS}_{2}$, fragment ions showing a neutral loss of sugar were observed at $\mathrm{m} / z 1699\left([\mathrm{M}-\mathrm{HexNAc}+\mathrm{Na}]^{+}\right), 1551$ $\left([\mathrm{M}-\mathrm{HexNAc}-\mathrm{Fuc}+\mathrm{Na}]^{+}\right), 1496\left([\mathrm{M}-2 \mathrm{HexNAc}+\mathrm{Na}]^{+}\right)$, $1349\left([\mathrm{M}-2 \mathrm{HexNAc}-\mathrm{Fuc}+\mathrm{Na}]^{+}\right), 1292([\mathrm{M}-3 \mathrm{HexNAc}$ $\left.+\mathrm{Na}]^{+}\right), 1145\left([\mathrm{M}-3 \mathrm{HexNAc}-\mathrm{Fuc}+\mathrm{Na}]^{+}\right), 942([\mathrm{M}$ $\left.-4 \mathrm{HexNAc}-\mathrm{Fuc}+\mathrm{Na}]^{+}\right)$, and $779([\mathrm{M}-4 \mathrm{HexNAc}-\mathrm{Fuc}-\mathrm{Hex}$ $+\mathrm{Na}]^{+}$), corresponding to CMS with $\mathrm{d} 16: 1 / \mathrm{C} 22: 0$ (Supplemental Fig. 1a). In the PSD mass spectrum of $\mathrm{COS}_{1}$, fragment ions showing a neutral loss of sugar were observed at $\mathrm{m} / \mathrm{z}$ $1901\left([\mathrm{M}-\mathrm{HexNAc}+\mathrm{Na}]^{+}\right), 1697\left([\mathrm{M}-2 \mathrm{HexNAc}+\mathrm{Na}]^{+}\right)$, $1494\left([\mathrm{M}-3 \mathrm{HexNAc}+\mathrm{Na}]^{+}\right), 1348([\mathrm{M}-3 \mathrm{HexNAc}-\mathrm{Fuc}$ $\left.+\mathrm{Na}]^{+}\right), 1145\left([\mathrm{M}-4 \mathrm{HexNAc}-\mathrm{Fuc}+\mathrm{Na}]^{+}\right), 941$ 


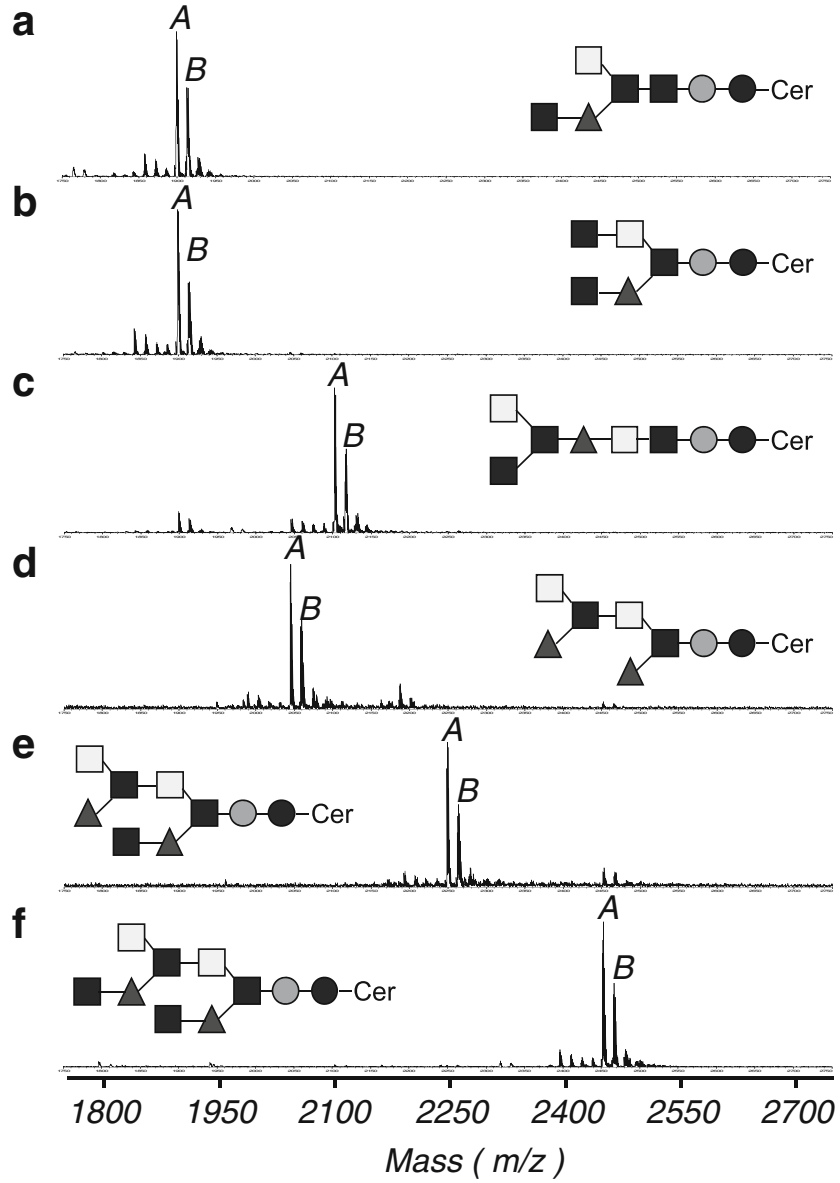

Fig. 3 Positive-ion reflector mode MALDI-TOF MS spectra of the separated GSLs. a $\mathrm{CHpS}_{1} ; A,[\mathrm{M}+\mathrm{Na}]^{+}$ion at $\mathrm{m} / \mathrm{z} 1899.47 ; B$, $[\mathrm{M}+\mathrm{Na}]^{+}$ion at $m / z 1913.42 ; \mathbf{b ~} \mathrm{CHpS}_{2} ; A,[\mathrm{M}+\mathrm{Na}]^{+}$ion at $m / z$ 1898.82; $B,[\mathrm{M}+\mathrm{Na}]^{+}$ion at $m / z$ 1912.78; $\mathrm{COS}_{1} ; A,[\mathrm{M}+\mathrm{Na}]^{+}$ion at $m / z 2101.84$; $B,[\mathrm{M}+\mathrm{Na}]^{+}$ion at $m / z 2115.81 ; \mathbf{d ~} \mathrm{COS}_{2} ; A,[\mathrm{M}+\mathrm{Na}]^{+}$ion at $m / z 2044.96$; $B,[\mathrm{M}+\mathrm{Na}]^{+}$ion at $m / z 2058.95$; e CNS; $A,[\mathrm{M}+\mathrm{Na}]^{+}$ion at $m / z 2248.38$; $B,[\mathrm{M}+\mathrm{Na}]^{+}$ion at $m / z 2262.31 ; \mathbf{f ~ C D e S} ; A,[\mathrm{M}+\mathrm{Na}]^{+}$ion at $m / z 2451.45$; $B,[\mathrm{M}+\mathrm{Na}]^{+}$ion at $\mathrm{m} / \mathrm{z} 2465.42$

$\left([\mathrm{M}-5 \mathrm{HexNAc}-\mathrm{Fuc}+\mathrm{Na}]^{+}\right)$, and $779([\mathrm{M}-5 \mathrm{HexNAc}-\mathrm{Fuc}$ $-\mathrm{Hex}+\mathrm{Na}]^{+}$), corresponding to CMS with $\mathrm{d} 16: 1 / \mathrm{C} 22: 0$ (Supplemental Fig. 1b). In the PSD mass spectrum of $\mathrm{COS}_{2}$, fragment ions showing a neutral loss of sugar were observed at $m / z 1901\left([\mathrm{M}-\mathrm{Fuc}+\mathrm{Na}]^{+}\right), 1843([\mathrm{M}$ $\left.-\mathrm{HexNAc}+\mathrm{Na}]^{+}\right), 1754\left([\mathrm{M}-2 \mathrm{Fuc}+\mathrm{Na}]{ }^{+}\right), 1697([\mathrm{M}$ $\left.-\mathrm{HexNAc}-\mathrm{Fuc}+\mathrm{Na}]^{+}\right), 1552\left([\mathrm{M}-\mathrm{HexNAc}-2 \mathrm{Fuc}+\mathrm{Na}]^{+}\right)$, $1494\left([\mathrm{M}-2 \mathrm{HexNAc}-\mathrm{Fuc}+\mathrm{Na}]^{+}\right), 1348([\mathrm{M}-2 \mathrm{HexNAc}$ $\left.-2 \mathrm{Fuc}+\mathrm{Na}]^{+}\right), 1290\left([\mathrm{M}-3 \mathrm{HexNAc}-\mathrm{Fuc}+\mathrm{Na}]^{+}\right), 1145([\mathrm{M}$ $\left.-3 \mathrm{HexNAc}-2 \mathrm{Fuc}+\mathrm{Na}]^{+}\right), 941\left([\mathrm{M}-4 \mathrm{HexNAc}-2 \mathrm{Fuc}+\mathrm{Na}]^{+}\right)$, and $779\left([\mathrm{M}-4 \mathrm{HexNAc}-2 \mathrm{Fuc}-\mathrm{Hex}+\mathrm{Na}]^{+}\right)$, corresponding to CMS with d16:1/C22:0 (Supplemental Fig. 1c). In the PSD mass spectrum of CNS, fragment ions showing a neutral loss of sugar were observed at $m / z 2104\left([\mathrm{M}-\mathrm{Fuc}+\mathrm{Na}]^{+}\right), 2047$ ([M $\left.-\mathrm{HexNAc}+\mathrm{Na}]^{+}\right), 1901\left([\mathrm{M}-\mathrm{HexNAc}-\mathrm{Fuc}+\mathrm{Na}]^{+}\right), 1698([\mathrm{M}$ $\left.-2 \mathrm{HexNAc}-\mathrm{Fuc}+\mathrm{Na}]^{+}\right), 1494\left([\mathrm{M}-3 \mathrm{HexNAc}-\mathrm{Fuc}+\mathrm{Na}]^{+}\right)$, $1348\left([\mathrm{M}-3 \mathrm{HexNAc}-2 \mathrm{Fuc}+\mathrm{Na}]^{+}\right), 1291([\mathrm{M}-4 \mathrm{HexNAc}$
$\left.-\mathrm{Fuc}+\mathrm{Na}]^{+}\right), 1144\left([\mathrm{M}-4 \mathrm{HexNAc}-2 \mathrm{Fuc}+\mathrm{Na}]^{+}\right), 941([\mathrm{M}$ $\left.-5 \mathrm{HexNAc}-2 \mathrm{Fuc}+\mathrm{Na}]^{+}\right)$, and $779([\mathrm{M}-5 \mathrm{HexNAc}-2 \mathrm{Fuc}$ $-\mathrm{Hex}+\mathrm{Na}]^{+}$), corresponding to CMS with $\mathrm{d} 16: 1 / \mathrm{C} 22: 0$ (Fig. 4b). In the PSD mass spectrum of CDeS, fragment ions showing a neutral loss of sugar were observed at $\mathrm{m} / \mathrm{z}$ $2250\left([\mathrm{M}-\mathrm{HexNAc}+\mathrm{Na}]^{+}\right), 2104([\mathrm{M}-\mathrm{HexNAc}-\mathrm{Fuc}$ $\left.+\mathrm{Na}]^{+}\right), 2046\left([\mathrm{M}-2 \mathrm{HexNAc}+\mathrm{Na}]^{+}\right), \quad 1900([\mathrm{M}$ $\left.-2 \mathrm{HexNAc}-\mathrm{Fuc}+\mathrm{Na}]^{+}\right), 1697\left([\mathrm{M}-3 \mathrm{HexNAc}-\mathrm{Fuc}+\mathrm{Na}]^{+}\right)$, $1494\left([\mathrm{M}-4 \mathrm{HexNAc}-\mathrm{Fuc}+\mathrm{Na}]^{+}\right), 1348([\mathrm{M}-4 \mathrm{HexNAc}$ $\left.-2 \mathrm{Fuc}+\mathrm{Na}]^{+}\right), 1290\left([\mathrm{M}-5 \mathrm{HexNAc}-\mathrm{Fuc}+\mathrm{Na}]^{+}\right), 1144([\mathrm{M}$ $\left.-5 \mathrm{HexNAc}-2 \mathrm{Fuc}+\mathrm{Na}]^{+}\right), 940\left([\mathrm{M}-6 \mathrm{HexNAc}-2 \mathrm{Fuc}+\mathrm{Na}]^{+}\right)$, and $778\left([\mathrm{M}-6 \mathrm{HexNAc}-2 \mathrm{Fuc}-\mathrm{Hex}+\mathrm{Na}]^{+}\right)$, corresponding to CMS with d16:1/C22:0 (Supplemental Fig. 1d).

Anomeric configurations of the sugar residues

Anomeric protons of the sugar residues in $\mathrm{CHpSes}$ and CDeS were analyzed by ${ }^{1} \mathrm{H}-\mathrm{NMR}$ spectroscopy (Fig. 5 and Table 3). The configurations of these residues were assigned by comparisons with similar data obtained on MacCer and $\mathrm{At}_{3} \mathrm{Cer}$ [19], $\mathrm{At}_{5} \mathrm{Cer}$ [20], Fuc [21], and $\alpha$ GlcNAc $[22,23]$ (Table 3). The anomeric assignments of $\alpha$-Fuc and $\alpha$-GlcNAc were determined by a downfield shift of the glycosyl-substituted fucose peak relative to that in the NMR spectrum of non-arthro-CTS [9], which was consistent with the data of $\mathrm{Xu}$ et al. [24]. Anomeric proton resonances are shown in Fig. 5 for each of the GSLs. The glycoside linkages in these compounds were also speculated. In the anomeric region of the spectrum for each GSL, the anomeric proton resonances are observed at $4.16 \mathrm{ppm}\left(J_{1,2}=\right.$ $7.8 \mathrm{~Hz})$ for $\beta$-Glc, at $4.52 \mathrm{ppm}\left(J_{1,2}=\sim 1 \mathrm{~Hz}\right)$ for $\beta$-Man, at 4.60 and $4.63 \mathrm{ppm}\left(J_{1,2}=8.2\right.$ and $9.1 \mathrm{~Hz}$, respectively) for $\beta$-GlcNAc, at $4.29 \mathrm{ppm}\left(J_{1,2}=8.2 \mathrm{~Hz}\right)$ for $\beta$-GalNAc, and at 4.99 and $4.98 \mathrm{ppm}\left(J_{1,2}=3.2\right.$ and $\left.2.7 \mathrm{~Hz}\right)$ for overlapped $\alpha$ Fuc and $\alpha$-GlcNAc (Fig. 5a, $\left.\mathrm{CHpS}_{1}\right)$; at $4.15 \mathrm{ppm}\left(J_{1,2}=\right.$ $7.8 \mathrm{~Hz})$ for $\beta$-Glc, at $4.51 \mathrm{ppm}\left(J_{1,2}=\sim 1 \mathrm{~Hz}\right)$ for $\beta$-Man, at 4.58 and $4.65 \mathrm{ppm}\left(J_{1,2}=7.3\right.$ and $7.8 \mathrm{~Hz}$, respectively) for $\beta$-GlcNAc, at $4.35 \mathrm{ppm}\left(J_{1,2}=7.8 \mathrm{~Hz}\right)$ for $\beta$-GalNAc, and at 5.01 and $5.02 \mathrm{ppm}\left(J_{1,2}=3.4\right.$ and $\left.3.6 \mathrm{~Hz}\right)$ for overlapped $\alpha$ Fuc and $\alpha$-GlcNAc (Fig. 5 b, $\mathrm{CHpS}_{2}$ ); at 4.15 or $4.16 \mathrm{ppm}$ $\left(J_{1,2}=6.4\right.$ or $\left.8.7 \mathrm{~Hz}\right)$ for $\beta$-Glc, at $4.52 \mathrm{ppm}\left(J_{1,2}=\sim 1 \mathrm{~Hz}\right)$ for $\beta$-Man, at 4.63 and $4.64 \mathrm{ppm}\left(J_{1,2}=7.3 \mathrm{~Hz}\right)$ for $\beta$-GlcNAc, at 4.32 and $4.34 \mathrm{ppm}\left(J_{1,2}=6.9\right.$ and $7.8 \mathrm{~Hz}$, respectively $)$ for $\beta$-GalNAc, at $5.01 \mathrm{ppm}\left(J_{1,2}=2.7 \mathrm{~Hz}\right)$ for overlapped $\alpha$-Fuc and $\alpha$-GlcNAc, and $4.84 \mathrm{ppm}\left(J_{1,2}=3.7 \mathrm{~Hz}\right)$ for terminal $\alpha$ Fuc (Fig. $5 \mathrm{~d}, \mathrm{CNS})$; at $4.15 \mathrm{ppm}\left(J_{1,2}=7.6 \mathrm{~Hz}\right)$ for $\beta$-Glc, at $4.51 \mathrm{ppm}\left(J_{1,2}=\sim 1 \mathrm{~Hz}\right)$ for $\beta$-Man, at 4.64 and $4.68 \mathrm{ppm}$ $\left(J_{1,2}=7.2\right.$ and $7.4 \mathrm{~Hz}$, respectively) for $\beta$-GlcNAc, at 4.34 and $4.37 \mathrm{ppm}\left(J_{1,2}=8.0\right.$ and $8.1 \mathrm{~Hz}$, respectively) for $\beta$ GalNAc, and at $5.02 \mathrm{ppm}\left(J_{1,2}=2.9 \mathrm{~Hz}\right)$ for overlapped $\alpha$ Fuc and $\alpha$-GlcNAc (Fig. 5e, CDeS). As for $\mathrm{COS}_{2}$, purity was low that significant high signals attributable to a contaminant were observed at the olefin signal region. Although 
Fig. 4 Representative positiveion PSD spectra in MALDI-

TOF MS of the separated GSLs. a $\mathrm{CHpS}_{1}$; b CNS. Black arrows indicate mass differences between fragments with a ceramide molecular group. Gray arrows indicate mass differences between fragments without a ceramide molecular group. All fragments were detected as sodium adducts. The spectrum of $\mathbf{b}$ was expanded by a factor of 5 in the low-molecular-weight region a
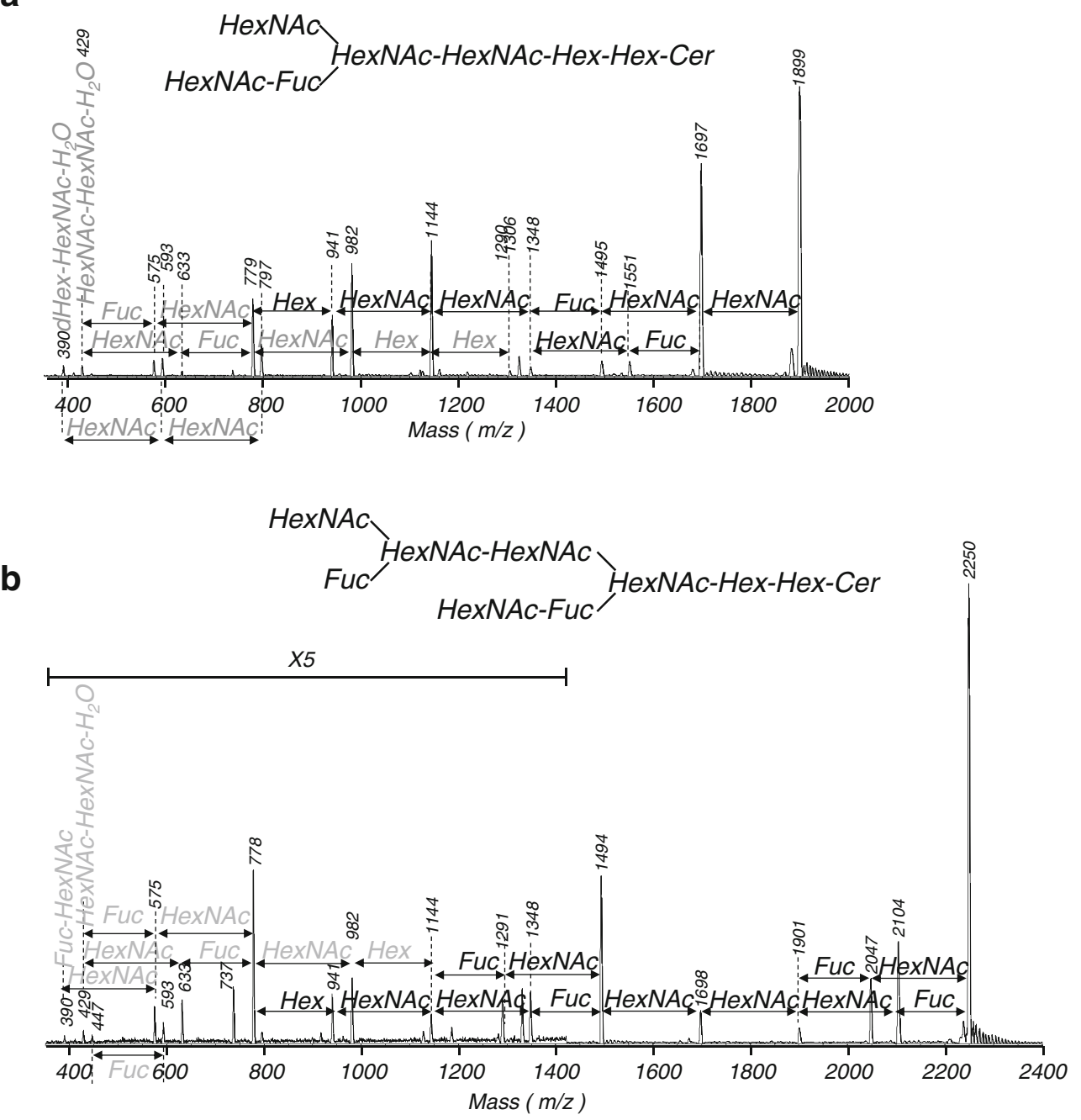

precise coupling constants could not be calculated, anomeric configuration and sugar species of $\mathrm{COS}_{2}$ were annotated according to chemical shift by comparing other NMR spectra of Artemia GSLs.

Speculated structures of the complex GSLs

The following complex GSL structures were speculated by means of the conventional analyses plus MALDI PSD measurements: IV $^{3}-($ GlcNAc $\beta)-\mathrm{III}^{3}-($ GlcNAc $\alpha 2$ Fuc $\alpha)$ $\mathrm{At}_{4} \mathrm{Cer}\left(\mathrm{CHpS}_{2}\right), \mathrm{IV}^{3}$-(fucosyl-LacdiNAc)-III ${ }^{3}-(\mathrm{GlcNAc} \alpha 2-$ Fuc $\alpha)-\mathrm{At}_{4} \mathrm{Cer}(\mathrm{CNS})$, and $\mathrm{IV}^{3}-(2-\alpha-N$-acetylglucosaminylfucosyl-LacdiNAc)-III ${ }^{3}$-(GlcNAc $\alpha 2$ Fuc $\left.\alpha\right)-\mathrm{At}_{4} \mathrm{Cer}$ (CDeS). The following complex GSL structures were also analyzed: $\mathrm{IV}^{3,4}-(\mathrm{GalNAc} \beta)-\mathrm{IV}^{3,4}-(\mathrm{GlcNAc} \alpha 2 \mathrm{Fuc} \alpha)-\mathrm{At}_{4} \operatorname{Cer}\left(\mathrm{CHpS}_{1}\right)$, GalNAc1-3,4(GlcNAc1-3,4)GlcNAc1-2Fuc1-3GalNAc14GlcNAc1-3Man1-4Glc1-Cer $\left(\mathrm{COS}_{1}\right)$, and IV $^{3}$ - (fucosylLacdiNAc) $-\mathrm{III}^{3}-(\mathrm{Fuc} \alpha)-\mathrm{At}_{4} \mathrm{Cer}\left(\mathrm{COS}_{2}\right)$. Although "1,3,4GlcNAc" was observed as a branching GlcNAc in both $\mathrm{CHpS}_{1}$ and $\mathrm{COS}_{1}$, it was impossible to confirm sugar substitution at the $\mathrm{C} 3 / \mathrm{C} 4$ position without hydrolysis analysis, which requires a large amount of $\mathrm{CHpS}_{1}$ and $\mathrm{COS}_{1}$.

\section{Discussion}

Structural characterization of complex GSLs can be a painstaking process because the results obtained by different analyses must converge on a single structure. For example, characterization by liquid chromatography-mass spectrometry (LC-MS) and tandem MS (MS-MS) provides accurate mass values of ceramide moieties, fatty acids, and sphingoids, but not of sugar species. It is also possible that liquid chromatographic separation would not be able to fully separate GSLs with different sugar chains of identical molecular weight. The conventional analyses, which consist of GC and MS, can be used to determine sugar species and molar ratios without overlooking the possibility of GSLs with different sugar chains of identical molecular weight. Another benefit of the conventional analysis is the ability to determine branching structures by 


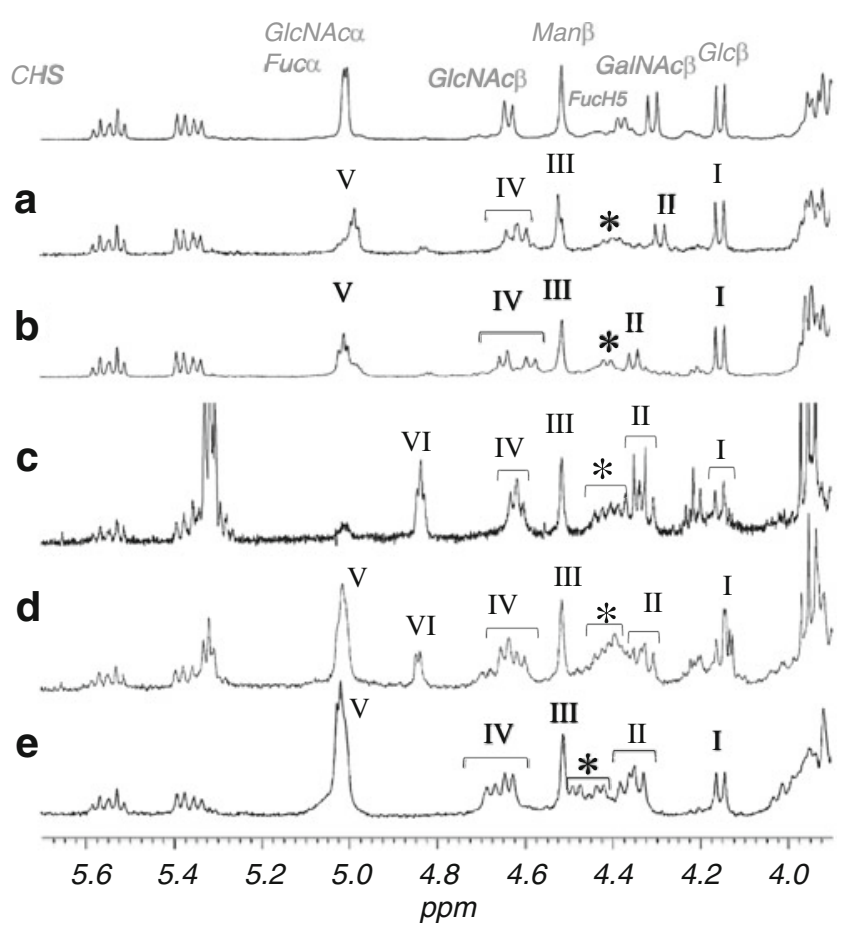

Fig. 5 Anomeric proton regions of the ${ }^{1} \mathrm{H}-\mathrm{NMR}$ spectra of the separated GSLs. a $\mathrm{CHpS}_{1}$; b $\mathrm{CHpS}_{2}$; $\mathbf{c} \mathrm{COS}_{2}$; d CNS; e CDeS; I: Glc $\beta$; II: GalNAc $\beta$; III: Man $\beta$; IV: GlcNAc $\beta$; V: Fuc $\alpha$ and GlcNAc $\alpha$; VI: Fuc $\alpha$; *: FucH5

hydrolysis. No matter the analysis, it is difficult to characterize complex GSLs because each result is also complex. A few decades ago, characterization of a complex GSL required $10 \mathrm{mg}$ of isolated GLS for chemical degradation, which liberated shorter GSLs, followed by GC analysis to determine sugar sequence and exoglycosidase treatment or chromic acid oxidation to determine anomeric configurations. In this study, we conducted MALDI PSD analysis to determine sugar sequence and ${ }^{1} \mathrm{H}$-NMR spectroscopy to identify anomeric configurations by using only 1-mg samples of each complex GSL separated from A. franciscana. Although PSD spectra of complex GSLs were confusing, sugar sequence analysis using sequences speculated from fragments, with the ceramide moiety observed in the high mass region, were consistent with sequences speculated from mere glycan fragments observed in the low mass region.

This study examined the structures of complex GSLs separated from the brine shrimp A. franciscana. Of them, a fucosylated LacdiNAc trisaccharide structure (GalNAc $\beta 1$ 4[Fuc $\alpha$ 1-3] GlcNAc $\beta$ ) was found in $\mathrm{CHpS}_{2}, \mathrm{COS}_{2}, \mathrm{CNS}$, and CDeS, similar to a previous report on CHS [9]. The trisaccharide structure is an analog of Lewis $\mathrm{X}$ and is also found in GSLs from the parasite $S$. mansoni [25] and in the carbohydrate portion of a human immunosuppressive glycoprotein, glycodelin [26].

The arthro-series core structure and a branching nonarthro-series disaccharide were also found in $\mathrm{CHpS}_{2}, \mathrm{CNS}$, and $\mathrm{CDeS}$, as described in previous reports on $\mathrm{nAtCTeS}$ and CHS. The $\alpha$-anomeric GlcNAc residue is rare, and there have been few reports of this residue among the carbohydrate portions of GSLs and glycoproteins. A human gastric mucin with an $\alpha$-anomeric GlcNAc residue could arrest the proliferation of Helicobacter pylori [27].

We speculate that $\mathrm{CHpS}_{2}$ is elongated with an additional Fuc $\alpha$ group, forming COS, and that COS is further elongated with branching GalNAc $\beta$ to form CNS. Although we could not separate COS as a direct precursor of CNS, we believe it exists in the biosynthetic pathway (Fig. 6). CNS is then finally elongated with an additional GlcNAc $\alpha$ to form CDeS. However, another branching residue on $\mathrm{CHpS}_{1}$ and $\mathrm{COS}_{1}$ indicates other biosynthetic pathways. A. franciscana GSLs with $\alpha$-anomeric GlcNAc at the nonreducing end do not seem to be elongated with further saccharides, which suggests the action of a "capping" mechanism. This theory is further supported by the observation that all of the $\alpha$ anomeric GlcNAc residues were reported at the nonreducing end $[9,22-24,28,29]$. Capping by an amino sugar in $A$. franciscana GSLs may be similar to the capping action of the 2-keto-3-deoxy-D-glycero-D-galacto-nononic acid $(\mathrm{KDN})$ residue in the rainbow trout Salmo gairdneri [30].

A series of structural analyses, including this study, has established the existence of sphingomyelin as a sphingophospholipid and GlcCer, MacCer, $\mathrm{At}_{3} \mathrm{Cer}, \mathrm{II}^{3} \mathrm{Fuc} \alpha$-MacCer (nonarthro-CTS), $\mathrm{At}_{4} \mathrm{Cer}, \mathrm{II}^{3}(\mathrm{GlcNAc} \alpha 2 \mathrm{Fuc} \alpha$ )-MacCer (nonarthro-CTeS), III ${ }^{3} \mathrm{Fuc} \alpha-\mathrm{At}_{4} \mathrm{Cer}$ (CPS), $\mathrm{III}^{3}$ (GlcNAc $\alpha 2$ Fuc $\alpha$ )-At $\mathrm{At}_{4} \mathrm{Cer}$ (CHS), $\mathrm{CHpS}_{1}, \mathrm{CHpS}_{2}, \mathrm{COS}_{1}, \mathrm{COS}_{2}, \mathrm{CNS}$, and CDeS as GSLs of $A$. franciscana. The complex GSLs reported this time are as the novel fucomannolipids. However, we confirmed that gangliosides and their functional alternative materials (other acidic GSLs) were below the limit of detection. In mammals, acidic GSLs such as gangliosides play important roles in the formation of the plasma membrane surface environment for signal transduction. It is interesting that $A$. franciscana can survive without significant amounts of acidic GSLs.

Performing structural analyses of complex GSLs in $A$. franciscana cysts, which are developmentally diapaused gastrulae, we established a GSL profile during embryonic development. Similar GSL analyses have been carried out in other species, including the frog Xenopus laevis [31], the chicken Gallus gallus domesticus [32], and the mouse Mus musculus [33]. However, all of these studies were conducted during the neurula stage or later, emphasizing the importance of timing in our study. A. franciscana is a very suitable organism for studying GSL profiles during early embryogenesis, as they require 5 days from fertilization to the gastrula stage.

In the brine shrimp $A$. franciscana, there are two reproduction patterns: oviparity, which generates diapausing eggs (cysts), and ovoviviparity, which generates nauplii. Oviparous 
Table 3 Summary of chemical shifts and $J_{1,2}$ coupling constants of anomeric protons in complex GSLs purified from A. franciscana

\begin{tabular}{|c|c|c|c|c|c|c|c|c|c|c|}
\hline \multicolumn{4}{|l|}{$\mathrm{CHpS}_{1}$} & $\begin{array}{l}\text { GalNAc1-3,4 } \\
\text { II }\end{array}$ & $\begin{array}{l}\text { (GlcNAc1- } \\
\mathrm{V}\end{array}$ & $\begin{array}{l}\text { 2Fuc1-3,4) } \\
\text { V }\end{array}$ & $\begin{array}{l}\text { GlcNAc1- } \\
\text { IV }\end{array}$ & $\begin{array}{l}\text { 3GlcNAc1- } \\
\text { IV }\end{array}$ & $\begin{array}{l}\text { 3Man1- } \\
\text { III }\end{array}$ & $\begin{array}{l}4 \mathrm{Glc} 1 \\
\mathrm{I}\end{array}$ \\
\hline \multicolumn{4}{|l|}{$\begin{array}{l}\text { Chemical } \\
\text { shifts (ppm) }\end{array}$} & 4.29 & $\begin{array}{l}4.98 \\
4.99\end{array}$ & $\begin{array}{l}4.98 \\
4.99\end{array}$ & $\begin{array}{l}4.60 \\
4.63\end{array}$ & $\begin{array}{l}4.60 \\
4.63\end{array}$ & 4.52 & 4.16 \\
\hline \multicolumn{4}{|l|}{$\begin{array}{l}\text { Coupling } \\
\text { constants }(\mathrm{Hz})\end{array}$} & 8.2 & $\begin{array}{l}2.7 \\
3.2\end{array}$ & $\begin{array}{l}2.7 \\
3.2\end{array}$ & $\begin{array}{l}8.2 \\
9.1\end{array}$ & $\begin{array}{l}8.2 \\
9.1\end{array}$ & $\sim 1$ & 7.8 \\
\hline \multicolumn{4}{|l|}{$\mathrm{CHpS}_{2}$} & $\begin{array}{l}\text { GlcNAc1-3 } \\
\text { IV }\end{array}$ & $\begin{array}{l}\text { GalNAc1-4 } \\
\text { II }\end{array}$ & $\begin{array}{l}\text { (GlcNAc1- } \\
\mathrm{V}\end{array}$ & $\begin{array}{l}\text { 2Fuc1-3) } \\
\mathrm{V}\end{array}$ & $\begin{array}{l}\text { GlcNAc1- } \\
\text { IV }\end{array}$ & $\begin{array}{l}\text { 3Man1- } \\
\text { III }\end{array}$ & $\begin{array}{l}4 \mathrm{Glc} 1 \\
\mathrm{I}\end{array}$ \\
\hline \multicolumn{4}{|l|}{$\begin{array}{l}\text { Chemical } \\
\text { shifts (ppm) }\end{array}$} & $\begin{array}{l}4.58 \\
4.65\end{array}$ & 4.35 & $\begin{array}{l}5.01 \\
5.02\end{array}$ & $\begin{array}{l}5.01 \\
5.02\end{array}$ & $\begin{array}{l}4.58 \\
4.65\end{array}$ & 4.51 & 4.15 \\
\hline \multicolumn{4}{|l|}{$\begin{array}{l}\text { Coupling } \\
\text { constants }(\mathrm{Hz})\end{array}$} & $\begin{array}{l}7.3 \\
7.8\end{array}$ & 7.8 & $\begin{array}{l}3.4 \\
3.6\end{array}$ & $\begin{array}{l}3.4 \\
3.6\end{array}$ & $\begin{array}{l}7.3 \\
7.8\end{array}$ & $\sim 1$ & 7.8 \\
\hline \multicolumn{2}{|l|}{ CNS } & $\begin{array}{l}\text { GalNAc1-4 } \\
\text { II }\end{array}$ & $\begin{array}{l}\text { (Fuc1-3) } \\
\text { VI }\end{array}$ & $\begin{array}{l}\text { GlcNAc1-3 } \\
\text { IV }\end{array}$ & $\begin{array}{l}\text { GalNAc1-4 } \\
\text { II }\end{array}$ & $\begin{array}{l}\text { (GlcNAc1- } \\
\mathrm{V}\end{array}$ & $\begin{array}{l}\text { 2Fuc1-3) } \\
\mathrm{V}\end{array}$ & $\begin{array}{l}\text { GlcNAc1- } \\
\text { IV }\end{array}$ & $\begin{array}{l}\text { 3Man1- } \\
\text { III }\end{array}$ & $\begin{array}{l}4 \mathrm{Glc} 1 \\
\mathrm{I}\end{array}$ \\
\hline \multicolumn{2}{|l|}{$\begin{array}{l}\text { Chemical } \\
\text { shifts (ppm) }\end{array}$} & $\begin{array}{l}4.32 \\
4.34\end{array}$ & 4.84 & $\begin{array}{l}4.63 \\
4.64\end{array}$ & $\begin{array}{l}4.32 \\
4.34\end{array}$ & 5.01 & 5.01 & $\begin{array}{l}4.63 \\
4.64\end{array}$ & 4.52 & $\begin{array}{l}4.15 \\
4.16\end{array}$ \\
\hline \multicolumn{2}{|l|}{$\begin{array}{l}\text { Coupling } \\
\text { constants }(\mathrm{Hz})\end{array}$} & $\begin{array}{l}6.9 \\
7.8\end{array}$ & 3.7 & $\begin{array}{l}7.3 \\
7.3\end{array}$ & $\begin{array}{l}6.9 \\
7.8\end{array}$ & 2.7 & 2.7 & $\begin{array}{l}7.3 \\
7.3\end{array}$ & $\sim 1$ & $\begin{array}{l}6.4 \\
8.7\end{array}$ \\
\hline $\mathrm{CDeS}$ & $\begin{array}{l}\text { GalNAc1-4 } \\
\text { II }\end{array}$ & $\begin{array}{l}\text { (GlcNAc1- } \\
\mathrm{V}\end{array}$ & $\begin{array}{l}\text { 2Fuc1-3) } \\
\mathrm{V}\end{array}$ & $\begin{array}{l}\text { GlcNAc1-3 } \\
\text { IV }\end{array}$ & $\begin{array}{l}\text { GalNAc1-4 } \\
\text { II }\end{array}$ & $\begin{array}{l}\text { (GlcNAc1- } \\
\mathrm{V}\end{array}$ & $\begin{array}{l}\text { 2Fuc1-3) } \\
\mathrm{V}\end{array}$ & $\begin{array}{l}\text { GlcNAc1- } \\
\text { IV }\end{array}$ & $\begin{array}{l}\text { 3Man1- } \\
\text { III }\end{array}$ & $\begin{array}{l}\text { 4Glc1 } \\
\text { I }\end{array}$ \\
\hline $\begin{array}{l}\text { Chemical } \\
\text { shifts (ppm) }\end{array}$ & $\begin{array}{l}4.34 \\
4.37\end{array}$ & 5.02 & 5.02 & $\begin{array}{l}4.64 \\
4.68\end{array}$ & $\begin{array}{l}4.34 \\
4.37\end{array}$ & 5.02 & 5.02 & $\begin{array}{l}4.64 \\
4.68\end{array}$ & 4.51 & 4.15 \\
\hline $\begin{array}{l}\text { Coupling } \\
\text { constants }(\mathrm{Hz})\end{array}$ & $\begin{array}{l}8.0 \\
8.1\end{array}$ & 2.9 & 2.9 & $\begin{array}{l}7.2 \\
7.4\end{array}$ & $\begin{array}{l}8.0 \\
8.1\end{array}$ & 2.9 & 2.9 & $\begin{array}{l}7.2 \\
7.4\end{array}$ & $\sim 1$ & 7.6 \\
\hline
\end{tabular}

eggs are resistant to dryness due to the existence of the heat shock protein p26 [34], which seems to be induced by environmental factors than by temperature. Nambu et al. [35] conducted experiments showing that certain conditions of light/dark cycles and temperature could affect the reproduction pattern of brine shrimp. GSLs have been shown to be involved in signaling, and signal transduction is, at least in part, responsible for the choice of oviparity or ovoviviparity. Therefore, this study, which provides a comprehensive analysis of GSLs in embryonic A. franciscana, might be of major significance in studies of embryogenesis and signal transduction.

A. franciscana contains complex GSLs such as CDeS, $\mathrm{CHpSes}$, and COSes. Other invertebrates containing complex GSLs with more than five sugar residues are [5] the flies $L$. caesar, C. vicina, Drosophila melanogaster (Insecta), the parasitic nematode Ascaris suum (Nematoda), the liver fluke Fasciola hepatica, the blood fluke S. mansoni (Platyhelminthes: Trematoda), the pseudophyllidean tapeworm Spirometra erinacei, the tapeworm Diphyllobothrium hottai (Platyhelminthes: Cestoda), the earthworm Pheretima hilgendorfi (Annelida: Oligochaeta), the annelidan worm Pseudopotamilla occelata (Annelida: Polychaeta), the bivalves $H$. schlegeli, C. sandai, M. lusoria, the oyster $O$. gigas (Mollusca), the abalone Haliotis japonica (Mollusca: Gatropoda), the lamp shell Lingula unguis (Brachiopoda), and the sea urchin Hemicentrotus pulcherrimus (Echinodermata). Of these, only half contain GSLs with the same number of sugar residues and a different sugar chain sequence. As in vertebrates, GSLs with multiple sugar chain sequences may exhibit tissue specificity. These GSLs can be roughly divided into two groups: one with straight complex GSLs, such as those found in flies, the nematode, the blood fluke, and the lamp shell, and those with branching complex GSLs. Complex GSLs with more than seven sugar residues have been reported as follows: GlcNAc $\beta 1$-3Gal $\beta 1$-3GalNAc $\alpha 1-4$ GalNAc $\beta 1-4 G l c N A c \beta 1-$ $3 \mathrm{Man} \beta 1-4 \mathrm{Glc} \beta 1-\mathrm{Cer}\left(\mathrm{At}_{7} \mathrm{Cer}\right)$ from the fly $C$. vicina [11]; $\mathrm{At}_{7} \mathrm{Cer}, \mathrm{VII}{ }^{3}-\beta$-GalNAc-At ${ }_{7} \mathrm{Cer}\left(\mathrm{At}_{8} \mathrm{Cer}\right)$, and $\mathrm{VIII}^{3}-\beta$-Gal$\mathrm{At}_{8} \mathrm{Cer}\left(\mathrm{At}_{9} \mathrm{Cer}\right)$ from the fly $L$. caesar [10]; Fuc $\alpha 3 \mathrm{Gal}-$ NAc $\beta 4$ (Fuc $\alpha 3$ )GlcNAc $\beta 3$ GlcNAc $\beta 3$ GalNAc $\beta 4$ Glc $\beta$ Cer, Fuc $\alpha 3$ GalNAc $\beta 4$ (Fuc $\alpha 2$ Fuc $\alpha 3$ )GlcNAc $\beta 3$ GlcNAc $\beta 3$ GalNAc $\beta 4$ Glc $\beta$ Cer, Fuc $\alpha 3$ GalNAc $\beta 4$ (Fuc $\alpha 2$ Fuc $\alpha 2$ Fuc $\alpha 3)$ GlcNAc $\beta 3$ GlcNAc $\beta 3$ GalNAc $\beta 4$ Glc $\beta$ Cer, and Fuc1-4 (Fuc 1-3)GlcNAc1-2Fuc1-4(Fuc 1-3)GlcNAc1-2Fuc1-4 (Fuc1-3)GlcNAc1-2Fuc1-4(Fuc1-3)GlcNAc1-3GalNAc13 GalNAc1-4Glc1-Cer from the blood fluke [12-14]; 


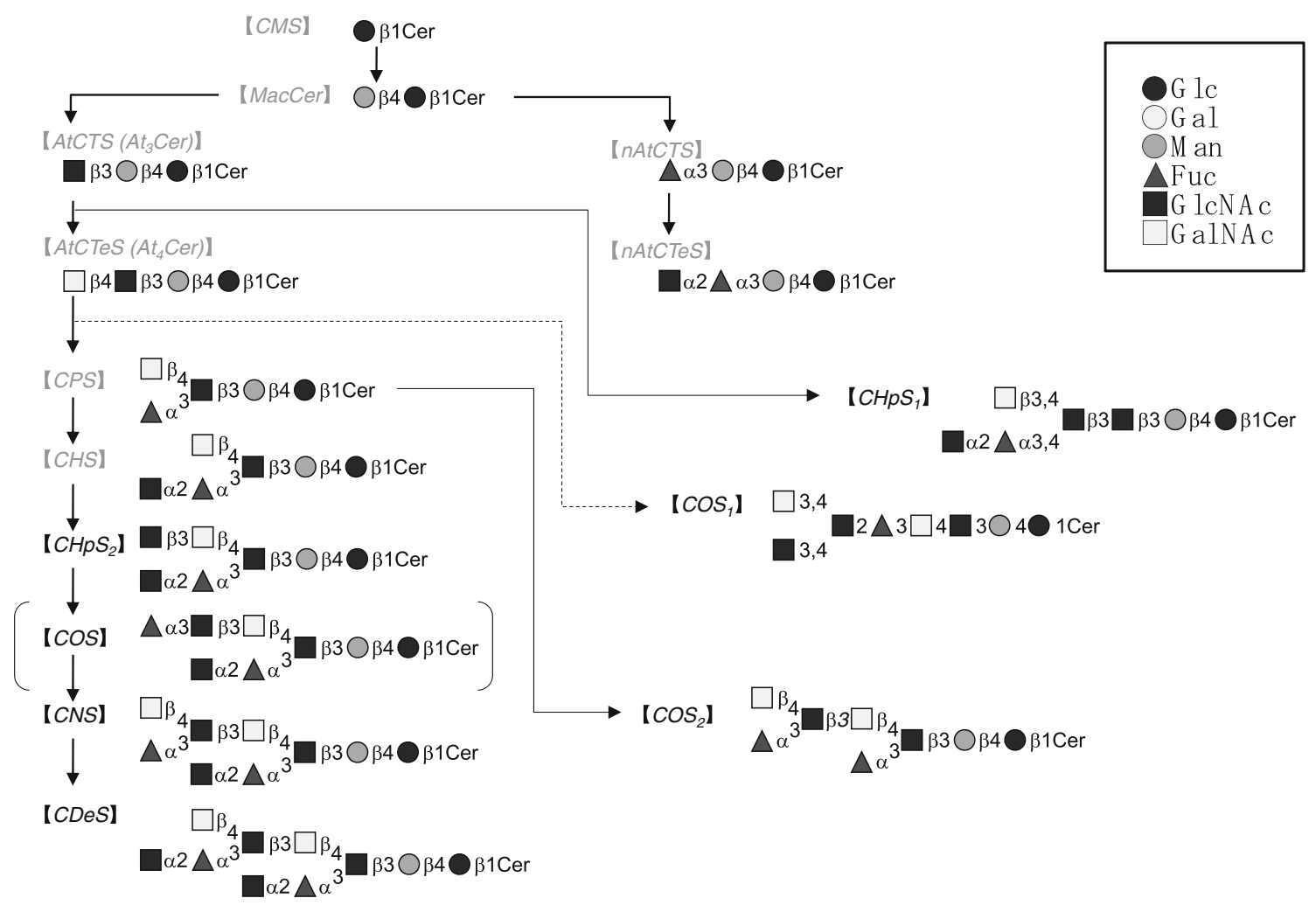

Fig. 6 Summary of the putative biosynthetic pathway of non-arthro and arthro-series neutral GSLs in the cyst of the brine shrimp

Gal4Me $\beta 1-3$ GalNAc $\beta 1-3$ Fuc $\alpha 1-4$ GlcNAc $\beta 1-2 M a n \alpha 1-3$ (Xyl $\beta 1-2)$ Man $\beta 1-4 G l c \beta 1-C e r$ (GL-1) from the bivalve $C$. sandai [15]; Fuc3Me $\alpha 1-2 \mathrm{Xyl3Me} \beta 1-4(G a l N A c 3 \mathrm{Me} \alpha 1-$ 3)Fuc $\alpha 1-4$ GlcNAc $\beta 1-2 \operatorname{Man} \alpha 1-3(\mathrm{Xyl} \beta 1-2) \operatorname{Man} \beta 1-4 \mathrm{Glc}$ $\beta 1-C e r$ (Lipid III) from the bivalves $H$. schlegeli and $M$. lusoria [16, 17]; and GlcNAc1-3(Fuc3Me $\alpha 1-2)$ Gal1-4GalNAc1-3[GalNAc3Me1-3(Fuc $\alpha 1-2)$ Gal1-2] Gal $\beta 1-3$ Gal $\beta 1$ $4 \mathrm{Glc} \beta 1$-Cer from the oyster [5]. All of these GSLs, with the exception of those found in the flies, contain a branching sugar chain and at least one fucose residue. In addition, almost all of the molluscan GSLs contain xylose and an $O$-methyl sugar residue. Organisms can also be divided into two groups according to the presence or absence of acidic or polar GSLs. The former group includes the flies and the bivalves. The latter group contains $A$. franciscana, the blood fluke, and the oyster. Furthermore, a fucosylated LacdiNAc structure and a GlcNAc $\beta 1-3$ GlcNAc disaccharide are common to both $A$. franciscana and the blood fluke. Shorter GSLs seem to be conserved within the same phyla while longer GSLs are more commonly unique to a given species.

This study of the entire GSL structure in A. franciscana showed that the ceramide composition is common among nearly all neutral GSLs, irrespective of the length of the sugar chain, with the exception of CMS, which contains hydroxy fatty acid, similar to millipedes [21], but not to flies such as $L$. caesar and $C$. vicina $[6,7,10,11,36]$. In arthropods, the dominant ceramide moieties are $\mathrm{d} 16: 1$ and smaller amounts of d17:1 as sphingoid; $\mathrm{C} 22: 0$ and smaller amounts of $\mathrm{C} 18: 0$ as fatty acid in A. franciscana; d17:1 and smaller amounts of branched d18:1 as sphingoid; C22:0 and smaller amounts of C23:0/C24:0 as fatty acid in the millipede; $\mathrm{d} 14: 1$ and smaller amounts of $\mathrm{d} 16: 1$ as sphingoid; $\mathrm{C} 20: 0$ and smaller amounts of C18:0/C22:0 as fatty acid in the flies and in the High Five insect cell line derived from the cabbage looper Trichoplusia $n i$ [37]. As mentioned above, the ceramide composition is found in both A. franciscana and the millipede, especially odd-numbered sphingoids, with the highest amount being C22:0. In addition, all of the neutral GSLs isolated from flies were straight, while the millipede contained a branching neutral GSL [21] and a ceramide phosphoryl ethanolamine (CPEA) [38] instead of the polar GSL with a molecular group of phosphoryl-ethanolamine, as found in flies [5]. A. franciscana contained branching neutral GSLs and sphingomyelin instead of a sphingolipid with a phosphoryl-ethanolamine group [39]. This commonality might indicate that $A$. franciscana is more closely related to the millipede than to insects.

Currently, it is not possible to use molecular biological approaches in brine shrimp because its genome has not been sequenced. However, there has been a report detailing the RNAi knockdown of a homeotic gene using microinjection [40]. It has been speculated that glycosyltransferases could 
be found in the arthropodal genomic sequences of $D$. melanogaster and other species, which might aid in the elucidation of a relationship between morphogenesis and the functions of GSLs in Crustacea.

Acknowledgments We would like to thank Prof. Mutsumi Sugita and Prof. Akemi Suzuki for helpful comments. We also thank Mr. Masahiro Sakane for additional experiments. This work was supported in part by the Grant-in-Aid for Scientific Research (C) (No. 22500276) and a grand of Strategic Research Foundation Grant-aided Project for Private Universities (No. S1001042).

Open Access This article is distributed under the terms of the Creative Commons Attribution License which permits any use, distribution, and reproduction in any medium, provided the original author(s) and the source are credited.

\section{References}

1. Hakomori, S.: Cell adhesion/recognition and signal transduction through glycosphingolipid microdomain. Glycoconj. J. 17, 143151 (2000)

2. Yu, R.K., Nakatani, Y., Yanagisawa, M.: The role of glycosphingolipid metabolism in the developing brain. J. Lipid Res. 50, S440-S445 (2009)

3. Kawano, T., Cui, J., Koezuka, Y., Toura, I., Kaneko, Y., Motoki, K., Ueno, H., Nakagawa, R., Sato, H., Kondo, E., Koseki, H., Taniguchi, M.: CD1d-restricted and TCR-mediated activation of $\mathrm{V}_{\alpha} 14$ NKT cells by glycosylceramides. Science 278, 1626-1629 (1997)

4. Yu, R.K., Yanagisawa, M., Ariga, T.: Glycosphingolipid structures. In: Kamerling, J.P. (ed.) Comprehensive Glycoscience from Chemistry to Systems Biology1: Introduction to Glycoscience; Synthesis of Carbohydrates, pp. 73-122. Elsevier, Oxford (2007)

5. Itonori, S., Sugita, M.: Glycophylogenetic aspects of lower animals. In: Kamerling, J.P. (ed.) Comprehensive Glycoscience from Chemistry to Systems Biology 3: Biochemistry of Glycoconjugate Glycans; Carbohydrate-Mediated Interactions, pp. 253-284. Elsevier, Oxford (2007)

6. Sugita, M., Nishida, M., Hori, T.: Studies on glycosphingolipids of larvae of the green-bottle fly, Lucilia caesar. I. Isolation and characterization of glycosphingolipids having novel sugar sequences. J. Biochem. 92, 327-334 (1982)

7. Dennis, R.D., Geyer, R., Egge, H., Menges, H., Stirm, S., Wiegandt, H.: Glycosphingolipids in insects. Chemical structures of ceramide monosaccharide, disaccharide, and trisaccharide from pupae of Calliphora vicina (Insecta: Diptera). Eur. J. Biochem. 146, 51-58 (1985)

8. Müller, R., Altmann, F., Zhou, D., Hennet, T.: The Drosophila melanogaster brainiac protein is a glycolipid-specific $\beta 1,3 N$-acetylglucosaminyltransferase. J. Biol. Chem. 277, 32417-32420 (2002)

9. Kojima, H., Shimizu, T., Sugita, M., Itonori, S., Fujita, N., Ito, M.: Biochemical studies on sphingolipids of Artemia franciscana: Novel neutral glycosphingolipids. J. Lipid Res. 52, 308-317 (2011)

10. Sugita, M., Inagaki, F., Naito, H., Hori, T.: Studies on glycosphingolipids in larvae of the green-bottle fly, Lucilia caesar: Two neutral glycosphingolipids having large straight oligosaccharide chains with eight and nine sugars. J. Biochem. 107, 899-903 (1990)

11. Dennis, R., Geyer, R., Egge, H., Peter-Katalinic, J., Li, S., Stirm, S., Wiegandt, H.: Glycosphingolipids in insects; chemical structures of ceramide tetra-, penta-, hexa-, and heptasaccharide from
Calliphora vicina pupae (Insecta: Diptera). J. Biol. Chem. 260, 5370-5375 (1985)

12. Levery, S.B., Weiss, J.B., Salyan, M.E., Roberts, C.E., Hakomori, S., Magnani, J.L., Strand, M.: Characterization of a series of novel fucose-containing glycosphingolipid immunogens from eggs of Schistosoma mansoni. J. Biol. Chem. 267, 5542-5551 (1992)

13. Khoo, K.H., Chatterjee, D., Caulfield, J.P., Morris, H.R., Dell, A.: Structural characterization of glycosphingolipids from the eggs of Schistosoma mansoni and Schistosoma japonicum. Glycobiology 7, 653-661 (1997)

14. Wuhrer, M., Kantelhardt, S.R., Dennis, R.D., Doenhoff, M.J., Lochnit, G., Geyer, R.: Characterization of glycosphingolipids from Schistosoma mansoni eggs carrying Fuc $(\alpha 1-3)$ GalNAc-, $\operatorname{GalNAc}(\beta 1-4)[\operatorname{Fuc}(\alpha 1-3)]$ GlcNAc- and $\operatorname{Gal}(\beta 1-4)[\operatorname{Fuc}(\alpha 1-3)]$ GlcNAc- (Lewis X) terminal structures. Eur. J. Biochem. 269, 481493 (2002)

15. Itasaka, O., Kosuga, M., Okayama, M., Hori, T.: Characterization of a novel ceramide octasaccharide isolated from whole tissue of a fresh-water bivalve, Corbicula sandai. Biochim. Biophys. Acta. 750, 440-446 (1983)

16. Hori, T., Sugita, M., Ando, S., Kuwahara, M., Kumauchi, K., Sugie, E., Itasaka, O.: Characterization of a novel glycosphingolipid, ceramide nonasaccharide, isolated from spermatozoa of the fresh water bivalve Hyriopsis schlegelii. J. Biol. Chem. 256, 10979-10985 (1981)

17. Sugita, M., Nakae, H., Yamamura, T., Takamiya, Y., Itasaka, O., Hori, T.: The occurrence of glycosphigolipids containing mannose in the sea-water bivalve, Meretrix lusoria. J. Biochem. 98, 27-34 (1985)

18. Svennerholm, L.: The quantitative estimation of cerebrosides in nervous tissue. J. Neurochem. 1, 42-53 (1956)

19. Schwientek, T., Keck, B., Levery, S.B., Jensen, M.A., Pedersen, J.W., Wandall, H.H., Stroud, M., Cohen, S.M., Amado, M., Clausen, H.: The drosophila gene brainiac encodes a glycosyltransferase putatively involved in glycosphingolipid synthesis. J. Biol. Chem. 277, 32421-32429 (2002)

20. Chen, Y., Pedersen, J.W., Wandall, H.H., Levery, S.B., Pizette, S., Clausen, H., Cohen, S.M.: Glycosphingolipids with extended sugar chain have specialized functions in development and behavior of Drosophila. Dev. Biol. 306, 736-749 (2007)

21. Sugita, M., Hayata, C., Yoshida, T., Suzuki, M., Suzuki, A., Takeda, T., Hori, T., Nakatani, F.: A novel fucosylated glycosphingolipid from the millipede Parafontaria laminata armigera. Biochim. Biophys. Acta 1215, 163-169 (1994)

22. Costantino, V., D'Esposito, M., Fattorusso, E., Mangoni, A., Basilico, N., Parapini, S., Taramelli, D.: Damicoside from Axinella damicornis: The influence of a glycosylated galactose 4-OH group on the immunostimulatory activity of $\alpha$-galactoglycosphingolipids. J. Med. Chem. 48, 7411-7417 (2005)

23. Wuhrer, M., Grimm, C., Zähringer, U., Dennis, R.D., Berkefeld, C.M., Idris, M.A., Geyer, R.: A novel GlcNAc $\alpha 1-\mathrm{HPO}_{3}-6 \mathrm{Gal}(1-1)$ ceramide antigen and alkylated inositol-phosphoglycerolipids expressed by the liver fluke Fasciola hepatica. Glycobiol. 13, 129-137 (2003)

24. Xu, X., Horibata, Y., Inagaki, M., Hama, Y., Sakaguchi, K., Goda, H.M., Okino, N., Ito, M.: A novel fucosyl glycosphingolipid of brine shrimp that is highly sensitive to endoglycoceramidase. Glycobiol. 19, 1446-1451 (2009)

25. Nyame, A.K., Yoshino, T.P., Cummings, R.D.: Differential expression of LacdiNAc, fucosylated LacdiNAc, and Lewis X glycan antigens in intramolluscan stages of Schistosoma mansoni. J. Parasitol. 88, 890-897 (2002)

26. Dell, A., Morris, H.R., Easton, R.L., Panico, M., Patankar, M., Oehninger, S., Koistinen, R., Koistinen, H., Seppala, M., Clark, G.F.: Structural analysis of the oligosaccharides derived from glycodelin, a human glycoprotein with potent immunosuppressive and contraceptive activities J. Biol. Chem. 270, 24116-24126 (1995) 
27. Kawakubo, M., Ito, Y., Okimura, Y., Kobayashi, M., Sakura, K., Kasama, S., Fukuda, N.M., Fukuda, M., Katsuyama, T., Nakayama, J.: Natural antibiotic function of a human gastric mucin against Helicobacter pylori infection. Science 305, 1003-1006 (2004)

28. Ishihara, K., Kurihara, M., Goso, Y., Urata, T., Ota, H., Katsuyama, T., Hotta, K.: Peripheral $\alpha$-linked $N$-acetylglucosamine on the carbohydrate moiety of mucin derived from mammalian gastric gland mucous cells: epitope recognized by a newly characterized monoclonal antibody. Biochem. J. 318, 409-416 (1996)

29. Nakayama, J., Yen, J.C., Misra, A.K., Ito, S., Katsuyama, T., Fukuda, M.: Expression cloning of a human $\alpha 1,4-N$-acetylglucosaminyltransferase that forms GlcNAc $\alpha 1 \rightarrow 4 \mathrm{Gal} \beta \rightarrow \mathrm{R}$, a glycan specifically expressed in the gastric gland mucous cell-type mucin. Proc. Natl. Acad. Sci. USA 96, 8991-8996 (1999)

30. Nadano, D., Iwasaki, M., Endo, S., Kitajima, K., Inoue, S., Inoue, Y.: A naturally occurring deaminated neuraminic acid, 3-deoxy-Dglycero-D-galacto-nonulosonic acid $(\mathrm{KDN})$. Its unique occurrence at the nonreducing ends of oligosialyl chains in polysialoglycoprotein of rainbow trout eggs. J. Biol. Chem. 261, 11550-11557 (1986)

31. Okamura, N., Kishimoto, Y.: Changes in nervous system glycolipids during metamorphosis of Xenopus laevis. J. Biol. Chem. 258, 12243-12246 (1983)

32. Rosner, H., Al-Aqtum, M., Rahmann, H.: Gangliosides and neuronal differentiation. Neurochem. Int. 20, 339-351 (1992)
33. Ngamukote, S., Yanagisawa, M., Ariga, T., Ando, S., Yu, R.K.: Developmental changes of glycosphingolipids and expression of glycogenes in mouse brains. J. Neurochem. 103, 2327-2341 (2007)

34. Liang, P., Macrae, T.M.: The synthesis of a small heat shock $/ \alpha$ Crystallin protein in Artemia and its relationship to stress tolerance during development. Dev. Biol. 207, 445-456 (1999)

35. Nambu, Z., Tanaka, S., Nambu, F.: Influence of photoperiod and temperature on reproductive mode in the brine shrimp, Artemia franciscana. J. Exp. Zool. 301A, 542-546 (2004)

36. Sugita, M., Iwasaki, Y., Hori, T.: Studies on glycosphingolipids of larvae of the green-bottle fly, Lucilia caesar. II. Isolation and structural studies of three glycosphingolipids with novel sugar sequences. J. Biochem. 92, 881-887 (1982)

37. Fuller, M.D., Schwientek, T., Wandall, H.H., Pedersen, J.W., Clausen, H., Levery, S.B.: Structure elucidation of neutral, di-, tri-, and tetraglycosylceramides from High Five cells: identification of a novel (nonarthro-series) glycosphingolipid pathway. Glycobiol. 15, 1286-1301 (2005)

38. Hori, T., Hayata, C., Nakatani, F., Yoshida, T., Sugita, M.: Occurrence of sphingoethanolamine in millipede Parafontaria laminata armigera. Bull. Shiga Bunka Coll. 3, 71-78 (1993). in Japanese

39. Kojima, H., Inoue, T., Sugita, M., Itonori, S., Ito, M.: Biochemical studies on sphingolipid of Artemia franciscana (I) isolation and characterization of sphingomyelin. Lipids 45, 635-643 (2010)

40. Copf, T., Schröder, R., Averof, M.: Ancestral role of caudal genes in axis elongation and segmentation. Proc. Natl. Acad. Sci. USA 101, 17711-17715 (2004) 